УДК 781.97:780.64(497.742)'’20'”(049.3)

https://doi.org/10.55302/MF2180127a

Горанчо Ангелов

\title{
ЗУРЛАЩИСКАТА ТРАДИЦИЈА ВО СТРУМИЧКО ВО 21 ВЕК
}

Апстракт: Предмет на истражување се зурлаџиско-тапанџиските состави во Струмичкиот Регион, кои успеале да се задржат и во време на глобализација и во интензивното навлегување на современи музички инструменти, кои, на некој начин, покрај зурлата и тапанот, ги потиснуваат и останатите традиционални инструменти.

Истражувањата во Струмичкиот Регион ни овозможуваат реално да ја согледаме денешната состојба со оваа постара инструментална традиција. Во трудот ќe бидат претставени зурлаџии и тапанџии од различни генерации, кои се носители на зурлаџиската традиција во Струмичкиот Регион во 21 век.

Во делот на музиката ќе го опфатиме зурлаџискиот стил во овој регион како и дел од зурлаџискиот репертоар.

Клучни зборови: зурла, зурлаџии, тапан, тапанџии, зурлаџиски групи.

Претстојното истражување е фокусирано на зурлаџиската традиција во Струмичкиот Регион во време кога бележиме забрзано исчезнување на она што се создавало и што се чувало со векови, традиција што е градена како резултат на неколку истовремени фактори. Создавањето, одржувањето и зачувувањето на која било инструментална традиција, вклучително и зурлаџиската, претставува комплексен процес во кој учествуваат свирачите со нивните инструменти, мајсторите-изработувачи на инструменти и аудиториумот како краен корисник на создадената музика. Свирачите се како посебна категорија луѓе, кои ја: негуваат, чуваат, пренесуваат и презентираат создадената и наталожена музика, а мајсторите-изработувачи на инструменти можеби се поневидливи од свирачите, но тие имаат своја улога во изработувањето и одржувањето на инструментите, кои, во рацете на свирачите, ја здобиваат својата музичка функција. Овие мајстори на инструменти, покрај изработувањето на инструментите, имаат важна улога и во нивното одржување, кое подразбира поправање или заменување на некој од составните делови. Аудиториумот, пак, е консуматор на создаваната музика, којашто неизоставно била присутна во различни контексти од животот на луѓето. Зурлаџиската инструментална традиција во РС Македонија, попрецизно, во Струмичкиот Регион, има повеќевековна традиција и зазема свое место во различни моменти од животот на луѓето. Навлегувањето на понови музички инструменти, кои не се карактеристични за постарата традиција, а паралелно со нив, навлегувањето и на современи музички влијанија, има одредена улога во потиснувањето на постарата зурлаџиска традиција и е неспорен фактот дека тоа се одразило и во денешниот број на свирачи на зурли и на тапани. Денес бројот на свирачи и зурлаџиски групи, споредено со минатото, е помал, но оваа традиција е зачувана и се негува од страна на талентираните свирачи, кои, како и пред векови наназад, од колено на колено си ја пренесуваат традицијата на свирење. Овие поединци, кои ја 
негуваат зурлаџиската традиција во 21 век, се показатели на улогата на зурлаџиската музика во различни моменти од животот на луѓето, и во минатото и денес. Зурлаџиската музика и нејзиниот карактеристичен звучен тембр се формираат како резултат на истовременото свирење на две или три зурли, и еден или два тапани. Ова го забележува и хрватскиот етномузиколог Божидар Широла, којшто вели дека свирењето на зурли не може да се замисли без тапан (Širola 1932: 55). Кога зборуваме за зурлаџиска музика, недвосмислено станува збор за музика во чие создавање учествуваат повеќе свирачи, кои, преку истовременото свирење на две зурли (една зурла свири мелодија, а друга - лежечки тон-бордун, дем, исо) и еден или два тапани ја свират ритмичката придружба. ${ }^{1}$

За состојбата со зурлаџиската традиција во РС Македонија, вклучително и во Струмичкиот Регион, информации добиваме од објавени публикации и од теренските истражувања, спроведени од нас, на оваа и денес жива инструментална традиција. Во Струмичкиот Регион имавме можност да регистрираме зурлаџии, тапанџии и зурлаџиски групи, кои во 21 век се носители на зурлаџиската традиција и со нивната музика учествуваат на различни настани во Струмичкиот и во други региони.

Во поглед на видот на зурли, кој се употребува во овој регион, Александар Линин забележува дека се употребувале јарам-каба и џура-зурли, кои освен во Струмичко, се употребувале и во Гевгелиско. Јарам-каба зурлите ги нарекува скойски, додека џура-зурлите, кои се употребувале само во Гевгелиско-струмичкиот Регион ги нарекува гевгелиско-сйрумички (Линин 1986: 108). Денес во Струмичкиот Регион се среќаваат само јарам-каба зурли. Штимот на зурлите се одредува според најнискиот тон, а зурлите во Струмичкиот Регион се во штим еs ${ }^{1}$ или $\mathbf{e}^{1}$ (најнизок тон $\mathbf{e s}^{1}$ или $\mathbf{e}^{1}$ ). ${ }^{2}$ Свирачите на музички инструменти во секој регион имаат одредено именување, именување кај кое етимологијата најчесто произлегува од самиот инструмент. Во досегаобјавените публикации, во кои е опфатена и зурлата во денешна РС Македонија, најчесто се употребува терминот зурлација (Линин 1986: 110; Симоновски 1999: 210); и поретко зурлаш и зурнаиија (Dević 1977: 129; Gojković 1989: 211). ${ }^{3}$ Андријана Гојковиќ го користи терминот зурлащија и за изработувачите на зурли (Gojković 1989: 211). Иста или слична терминологија среќаваме и во соседна Бугарија. Терминот зурлација (мн. зурлации) се среќава и во Р Бугарија (Качулев 1962: 199). Свирачот на зурла во

\footnotetext{
${ }^{1}$ Кога зборуваме за инструментална традиција во чие градење учествуваат свирачот со својот инструмент, како и музиката која тој ја свири, несомнено станува збор за еден свирач кој создава музика на својот инструмент.

2 Треба да се земе предвид дека станува збор за нетемпериран инструмент со варијабилна тонска висина, односно, најнискиот тон кај зурлите може да варира и да биде за нијанса понизок или повисок, со што се снижува или повишува целата тонска низа.

3 Според нас, овој термин веројатно се користи во регионите каде делумно или целосно преовладува српскиот јазик.
} 
Струмичкиот Регион се нарекува зурлација. Зурлаџиите потоа се делат на мајстор (оној што ја води мелодијата) и на придружник (оној што свири еден статичен бордунски тон). Придружниот зурлаџија се нарекува и яемиија или

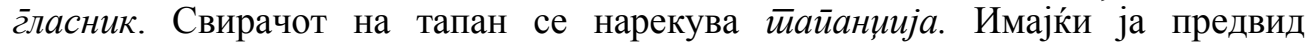
мултиетничноста на населението, кое живеело и сѐ уште живее на територијата на РС Македонија, при истражувањата на постарата инструментална традиција се наметнуваат и прашањата: кој свири на некој инструмент, на која етничка група ѝ припаѓаат свирачите, од која етничка група е прифатена и се бара музиката исполнета на инструментот, дали свират мажи и жени итн. Правејќи преглед на етничката припадност на свирачите на зурла и тапан од кои се составени зурлаџиските групи во Струмичкиот Регион, но и во останатите региони на РС Македонија, доаѓаме до заклучок дека оваа состојба не е многу променета споредено со состојбата во минатото. Бројни извори посочуваат дека главни носители на зурлаџиската традиција во РС Македонија во минатото и денес се припадниците на ромската етничка заедница со муслиманска вероисповед (Павловић 1929: 327; Đorđević 1926: 383-396; Голабовски 1974: 37; Gojković 1983: 71; Линин 1986: 110-111; Gojković 1989: 28; Ангелов 2015; Angelov 2016; Ангелов 2016). Оваа констатација се однесува и за Струмичкиот Регион каде и во минатото и денес, носители на оваа традиција се Роми помеѓу кои со генерации, од колено на колено се пренесувал и сѐ уште се пренесува зурлаџискиот занает. ${ }^{4}$ Зурлаџиската музика пак е прифатена од речиси сите етнички групи, а во поглед на половата застапеност, на зурла и тапан, и во минатото и денес свират само мажи. На што се должи тоа, не можеме со сигурност да кажеме и претпоставуваме дека тоа е резултат на патријархалноста која владеела на овие простори во минатото, но и на тежината за свирење на овие инструменти кои бараат поголем физички напор и сила. Во Струмичкиот Регион, музичките групи составени од зурли и тапан се нарекуваат зурлациски грруйи. Александар Линин за зурлаџиските групи бележи и термин ромски инсйруменйални состиави (Линин 1986: 121). Овој термин се должи на етничката припадност на зурлаџиите и тапанџиите и директно посочува кој свири на овие инструменти. Зурлаџиските групи во Струмичкиот Регион, и во минатото и денес, се составени од две зурли и еден тапан, но денес среќаваме и една зурлаџиска група која редовно настапува во состав од три зурли и еден или два тапани, која претставува исклучок од воспоставената традиционална пракса. Зурлаџиско-тапанџиските групи се составени од зурли со ист штим без разлика дали свират две или три зурли. Ритмичката придружба во зурлаџиските групи ја сочинува голем тапан кој со својата звучност продира помеѓу моќниот, силен и пискав тембр на зурлите. Во продолжение ќе направиме преглед на зурлаџии и тапанџии кои сѐ уште се активни и

\footnotetext{
4 Денес во Струмица бележиме и зурлаџии припадници на македонската етничка заедница со христијанска вероисповед, кои свират на други инструменти и немаат претходна традиција на свирење, и истите ќе бидат опфатени во друг труд.
} 
учествуваат во различни контексти, а кои ни даваат информации за свирачи кои делувале во минатото и дале свој придонес во зачувувањето и пренесувањето на зурлаџиската музика. Како една карактеристика за зурлаџиите е тоа што најголем дел од нив знаат да свират и на тапан, а некои тапанџии во одреден период од својот живот почнале да свират и на зурла.

Нашите информатори ни даваат одредени информации поврзани со струмичките зурлаџии и тапанџии кои делувале во минатото, и кои со своето музичко делување и учествување во различни контексти оставиле траен белег. 5 Тие споменуваат неколку зурлаџии и тапанџии и имаат и свои коментари за нивното свирење. Едни од најстарите зурлаџии на кои се сеќаваат нашите информатори се зурлаџиите: Исим, Абди, Мемет, Амет, Себатит (Себатија), Исмет Мемедов, Даут Јусеинов (роден 1941 год.). Зурлаџијата Абди бил по потекло од Радовиш, но се доселил и живеел во селото Градошорци. Абди во своето време на музичко делување важел за многу добар мајстор. Себатит Јусеинов од Струмица вели: По селайа имаме

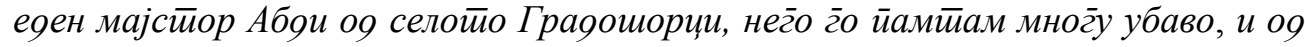

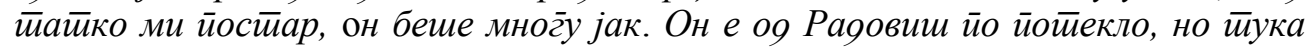

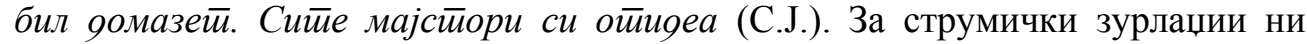
зборуваше и велешкиот зурлаџија Ихмет Усеинов: Во Сйрумица во

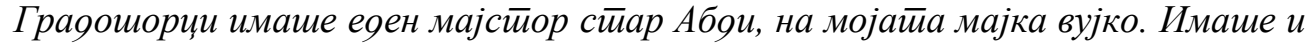
яруг̄и во Сйрумииа: Дауй, Себайија, имаше (И.У.).

Денес во втората деценија од 21 век, во Струмица и Струмичко активно свират неколку зурлаџии и тапанџии кои се дел од зурлаџиските групи во овој регион. Највозрасниот активен зурлаџија кој сѐ уште свири е Демир Мемедов, роден 1955 год. Демир е син на Исмет Мемедов и долги години бил тапанџија во зурлаџиски групи со неговиот татко и со зурлаџијата Даут. По смртта на овие зурлаџии, Демир почнува да свири на зурла и повеќе од дваесет години е зурлаџија и вели: Ја йослеяно зурлаиија исйаяна (Д.М.). Демир е пример за почнување со свирење на зурла во повозрасни години, за што самиот вели дека немал никаков проблем. За овој зурлаџија свирењето во зурлаџиска група со повозрасни зурлаџии било мошне полезно, бидејќи тој имал можност долги години да ја акумулира зурлаџиската музика од неговиот татко. Друг активен зурлаџија и тапанџија во Струмица е Себатит Јусеинов роден 1965 год., син на зурлаџијата Даут. ${ }^{6}$ Себатит е тапанџија во составот на Демир, но повремено свири и придружна зурла. Себатит за Демир и за неговиот татко Исмет вели:

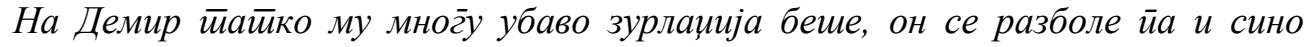

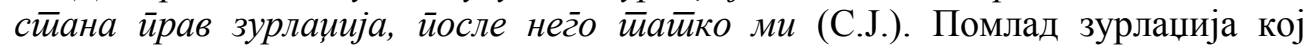
занаетот го учи од Демир е Изет Абдиев којшто свири придружна зурла и

\footnotetext{
${ }^{5}$ Пренесените информации не се целосни во поглед на години на раѓање и умирање, но за нас се драгоцени бидејќи преку споменувањето на имињата, овие свирачи остануваат запишани, со што им оддаваме големо признание за нивната заслуга во пренесувањето на зурлаџиската музика.

${ }^{6}$ Овој зурлаџија вели дека го носи името на татко му на тапанџијата Изет и вели дека Себатит Мемедов бил голем мајстор, но свирел придружна зурла на Даут.
} 
тапан во составот на Демир. ${ }^{7}$ Себатит Јусеинов и Изет, во текот на свирењето се менуваат со инструментите односно, едниот свири на тапан, а другиот држи дем и обратно. Од помладите зурлаџии денес активен е Џејан Агушев, роден 1992 год. Џејан учи и свири со Себатит и веќе е изграден зурлаџија. Еден од најмладите зурлаџии кој исто така го изучува зурлаџискиот занает од Демир е синот на Изет, Себатит Абдиев, роден 1995 год. Во струмичкото село Банско живеат тројца зурлаџии од иста фамилија кои се родени во градот Штип, но се иселени во с. Банско. Највозрасниот зурлаџија е Садик Сулејманов, кој е роден 1969 год., а неговите синови се, Абди роден 1988 год. и Амте роден 1991 год. И овие зурлаџии имаат фамилијарна традиција на свирење на зурла, а пред Садик на зурла свиреле неговиот дедо Шаин и неговиот татко Амет. Садик вели дека тој бил мал кога починал татко му, по чија смрт тој продолжил да свири со групата на татко му. На $\bar{u} р и н а е с \bar{w}$

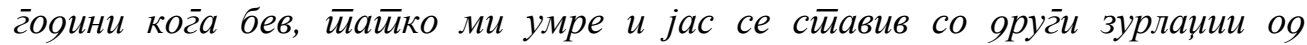

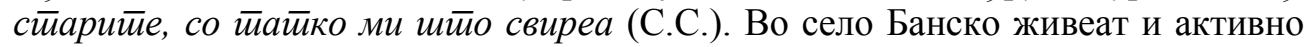
свират и неколку тапанџии кои имаат фамилијарна традиција на свирење на тапан. Тоа се тапанџиите Ѓунер Мустафов, роден 1980 год. и неговите синови: Рустем, роден 1999 год. и помладиот син Умут, роден 2002 год. Овие тапанџии се родени и живеат во с. Банско. Тапанџија бил и татко му на Гунер, по име Рустем кој бил роден во с. Бајково, Струмичко. Младиот Рустем долги години свири со зурлаџиската група на Садик Сулејманов. Претходно со оваа група свирел неговиот татко Гунер. Со зурлаџиската група Сулејманови, одреден период на тапан свирел и извесен Лато од Берово, што укажува на соработката на зурлаџии и тапанџии од различни региони. Овие зурлаџии велат дека соработката со добри тапанџии и зурлаџии е пресудна за нивното свирење. Ние сме знаеш ший? - Оркесӣар. Ние сме еgен мег̆уy яруг̄ не бива, и без йайанар и йайанаро без мене не бива (А.С.). Ни йа ние без нег̄о не можеме яа бияеме (С.С.). Ние сме чейворка злайна, чейворка и злайна зурла (А.С.). Дека улаваме, нема назая (С.С.). Не се йлашам у Макеоонија шо има зурлации, оя никој. Кој мисле яека може яа свире со мене може слобояно gа gojge или јас gа му ояам gома (А.С.). И йоа нот̄арски, како сака ќе

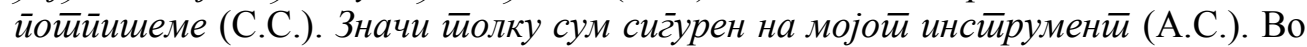
зурлаџиската група на Садик, главен мајстор е неговиот син Абди којшто е еден од најпрочуените млади зурлаџии во РС Македонија и надвор од неа, а со тоа и нивниот зурлаџиски состав којшто е многу баран во сите региони од државата. Другиот син на Садик, Амте, свири придружна зурла. Садик свири и прва и придружна зурла. За зурлаџиската група на Садик ќе кажеме дека тие настапуваат низ цела држава и надвор од неа. Ова се должи на живите настапи, но и на интернетот како средство за споделување на нивни музички видеа со што се достапни за аудиториумот и надвор од нивното место на живеење. Оваа форма на презентација на нивната музика им овозможува да бидат барани и во странски држави.

\footnotetext{
${ }^{7}$ Според националната припадност, Демир и Себатит се изјаснуваат како Турци.
} 
Музиката како краен производ на взаемното дејствување на свирачот и инструментот, формира и соодветно созвучје кое е резултат на истовременото свирење на повеќе од еден инструмент. Веќе кажавме дека зурлаџиските групи во Струмичкиот Регион се составени од две јарам-каба зурли и еден тапан со тоа што во овој регион егзистира зурлаџиската група која редовно настапува во состав од три зурли и еден тапан. Најистакнатата и сама по себе уникатна карактеристика на зурлаџиската музика е употребата на посебната техника на дување и дишење применувана од страна на зурлаџиите. Оваа техника овозможува при свирење мелодијата да не се прекинува, што е вообичаена пракса кај останатите дувачки инструменти, техника која зурлаџиите ја изучуваат уште на самиот почеток на нивното изучување на инструментот. Феликс Хоербургер оваа посебна и уникатна техника на дување и дишење ја нарекува quшење на нос (Hoerburger 1986: 251), додека Драгослав Девич ја нарекува истиочна йехника (Dević 1977: 131). Терминот quшене на нос дава конкретна насока за каква техника станува збор, додека

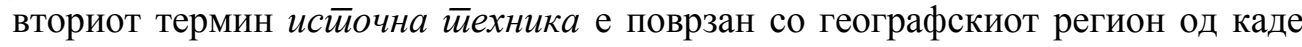
веројатно потекнува оваа техника на свирење употребувана од свирачите на зурли и инструментите слични на неа во источните земји. Струмичките зурлаџии оваа посебна техника на дишење ја нарекуваат со термините вазgух или солуф (С.С.), односно земеш возяух (А.С.). Солуф ја викаме йо йурски, йо макеоонски ја викаме вазяух, свиреш со вазяух (С.С.). Вияи сег̄а йоа е земеш возяух (А.С.). Техниката на непрестајно дување се изведува така што зурлаџијата го внесува воздухот во дијафрагмата преку носот, а потоа потрошениот воздух го враќа во образите кои му служат како резервоар за воздух (слично како кај мевот на гајдата). Од образите, воздухот рамномерно се испушта во писката. Континуираното рамномерно испуштање на воздухот овозможува задржување на интонацијата кај зурлата, што значи дека и самото испуштање на воздухот и постигнатиот притисок имаат своја улога во севкупното звучење на инструментот. Оваа техника на свирење се употребува и од страна на сите струмички зурлаџии. За зурлаџиската музика друга карактеристика е и тоа што мелодиите секогаш се изведуваат само инструментално и во придружба на зурлаџиско свирење, и не се пее. Што подразбира тоа? Без разлика дали на зурлата се свират ора или песни, тие секогаш се изведуваат само на зурла, без пеење. Една од причините е тоа што станува збор за дувачки инструменти кај кои мелодиите не се прекинуваат за земање воздух благодарение на посебната техника на дување, со што самите свирачи кои би требало да пеат се оневозможени за такво нешто. Другата причина е тоа што звучниот интензитет со кој се одликуваат зурлите и тапаните, и интензитетот кој се добива во текот на истовременото свирење на зурлите и тапанот, е прегласен за човечкиот глас и можности. Ние имавме ретка можност да проследиме пеење од страна на зурлаџии во локална продавница во с. Чалакли, Валандовско. Зурлаџиската група на Садик Сулејманов свиреше на гости во локална продавница за време на празникот Ѓру́́ овден, а во еден момент зурлаџиите престанаа да свират и почнаа да ја

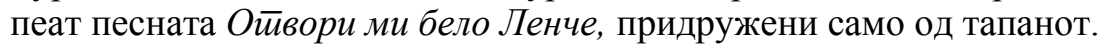


Интерпретирањето на зурлаџиската музика е на тој начин што едниот зурлаџија свири мелодија, свири импровизации и го води репертоарот, а другиот зурлаџија го придружува со свирењето на еден статичен бордунски тон (дем) кој лежи на основниот тон од интерпретираната мелодија. Бордунскиот тон се менува кога се менува тоналниот центар на мелодијата. Кај струмичкиот зурлаџиски стил забележуваме и повремено напуштање на бордунскиот тон и појава на дуплирање на мелодијата односно појава на хетерофонија. Хетерофонијата може да биде преку удвојување на мелодијата во унисон или во октава. Во поново време, особено кај помладите зурлаџии, среќаваме свирење и во терци и сексти. Појавата на хетерофонијата може да биде спонтана (случајна, несвесна) и да се појавува на различно место при секоја следна изведба на една иста мелодија, но може и да е постојана и секогаш да се јавува на исто место. Кога појавата на хетерофонија е спонтана, таа настанува како моментално чувство на придружниот зурлаџија да го напушти бордунот и во еден краток момент пак да се врати на бордунскиот тон. Кога хетерофонијата се појавува секогаш на исто место во мелодијата, таа е свесно осмислена и има функција да нагласи некој мелодиски момент во самата мелодија. Тапанџиите свират ритмички обрасци во ритамот на мелодијата, а во нивното свирење многу често се присутни бројни ритмички варијации. Преку овие ритмички варијации тапанџиите ја збогатуваат мелодијата, а воедно ги истакнуваат и нивните свирачки вештини. Ова влијание на ритмичко произнесување според струмичките зурлаџии се должи на нивните контакти и близина со зурлаџиите од Петрич, Бугарија, кај кои ритамот се произнесува на еден изразито темпераментен начин. Во зурлаџиската група составена од три зурли и еден тапан сите зурлаџии се мајстори, но еден ја свири мелодијата, еден свири бордунски тон, а третиот свири и мелодија и бордун, односно ја удвојува мелодијата (во унисон, терца, секста или октава) или го удвојува бордунскиот тон. Поради ваквиот начин на свирење во овој состав, покрај удвоениот бордун и мелодија, имаме појава и на трогласна хетерофонија. Имитацијата на мелодијата како појава кај овој состав е поретко застапена и таа најчесто е спонтана, поради задоцнето влегување во мелодијата од страна на придружниот зурлаџија.

Музичкиот репертоар кај струмичките зурлаџии се прилагодува на приликите во кои свират, како и на етникумот кој има потреба од нивната музика, но во Струмичкиот Регион се бара и постарата зурлаџиска музика која овие зурлаџии сѐ уште ја негуваат, а во нивниот репертоар се застапени и песни и ора кои имаат поново потекло, а се популарни и барани од народот. Репертоарот, зурлаџиите го градат во текот на нивниот зурлаџиски живот и тој се состои од песни и ора карактеристични за Струмичкиот Регион, но и песни и ора кои се бараат и во останатите региони, каде што свират овие зурлаџии. Ова е причината што во изведуваните мелодии се препознаваат многубројни песни и ора како дел од изведувачкиот репертоар, но се среќаваат и други, чисто инструментални мелодии. Овие мелодии не се базираат на вокални напеви или на ора, но исто така се составени од дефинирани музички фрази оформени како засебни мелодии кои при секое изведување се свират исто. Во зурлаџиската музика често се присутни и 
мелодии кои се создаваат во моментот на свирење и настануваат како израз на творечката способност на свирачот. Овие моментално создадени мелодии се нарекуваат импровизации поради начинот на кој се создаваат. Друга појава кај зурлаџиската музика е варијантноста на изведуваните мелодии, што се должи на усното пренесување на мелодиите од еден на друг зурлаџија, но и на слободата на изведување при секое наредно свирење на една иста мелодија. Појавата на импровизации и варијантност се карактеристични за фолклорната музика и се присутни и кај изведувачите и на другите народни инструменти.

Зурлаџиската музика во Струмичкиот Регион зазема свое место во различни моменти од животот на населението, население кое го сочинуваат припадници на различни етнички групи. Ние веќе кажавме дека свирачите на зурли и тапани од кои се составени зурлаџиските групи припаѓаат на ромската етничка заедница. Имајќи го ова предвид, се поставува прашањето дали овие свирачи со нивната музика го опслужуваат само ромскиот етникум, или свират и на останатите етнички групи. Бројни досегашни извори кои ги поткрепивме и со нашите истражувања, укажуваат на тоа дека зурлаџиската музика е прифатена од речиси сите етнички групи. Нашите информатори велат дека нивната етничка припадност не претставува никаква пречка, свирената од нив музика да биде прифатена од сите етнички групи кои живеат во Струмичкиот и во останатите региони од државата. Оваа категорија на луѓе, целиот свој живот го посветуваат на совладување на инструментот, на техничко усовршување, на совладување на репертоарот и негово произнесување пред аудиториумот како краен консуматор на изведуваната музика. Со самото тоа што зурлаџиите во текот на својот свирачки живот посветуваат големо внимание на совладување на музичкиот репертоар кој се бара од различните етнички групи, им го отворил патот тие да можат музички да одговорат на побарувањата на аудиториумот од различните етнички групи. Музичката подготвеност која кај зурлаџиите и тапанџиите е на високо професионално изведувачко ниво, им овозможува изведуваната музика да ја прилагодуваат на оној кому му свират. Умешноста на свирачите да ја прилагодуваат музиката на оној кому му свират, ја истакнува нивната посветеност во совладувањето на обемен музички репертоар наменет за различните етнички групи. Според зурлаџиите, зурлаџиската музика се бара од Роми, Турци, Турци Јуруци, Албанци, Торбеши и од Македонци. Оваа прифатеност на зурлаџиската музика од страна на различните етнички групи укажува на мултиетничноста на зурлаџиската музика, музика создадена од инструментите и свирачот кој ја има улогата на медијатор помеѓу инструментот, музиката и аудиториумот.

Свирачите со својата музика се присутни во различни контексти од животот на луѓето. Со самото тоа што свирачот со неговото присуство станува дел од најразлични настани, тој се здобива и со одредена функција во практикувањето на некои обреди. Светлана Захариева ја укажува улогата на свирачот како значаен фундамент во инструменталната музика и вели дека тој е обредно лице со посебна функција која го разликува од другите обредни лица, нијансирајќи му го значењето во рамките на унифицирана семантика и истовремено, на чуден начин се запечатува во звучната партитура на обредот. 
Захариева посочува дека свирачот не е само придружник којшто со својата музика носи само веселба, туку таа негова функција (неопходен фон на празнична веселба) е многу важна и на прв поглед се истакнува како основна (Захариева 1987: 81). Карактеристичниот звучен тембр на зурлаџиските групи, тембр кој се јавува како резултат на истовременото свирење на две зурли и еден или два тапани, претставува своевидна реминисценција на минатото манифестирана преку навидум едноставната за слушање, но, сложена за свирење музика. Оваа реминисценција пак, истовремено е и звучна асоцијација на празничност, радост, веселба, среќа. Во Струмичкиот Регион зурлаџиската музика е присутна за време на различни семејни настани како: свадби, веридби (армас), раѓање на дете, осветување на куќа. Кај муслиманското население зурлаџиската музика е присутна на обредот кога се сунетисуваат машките деца, обред кој се нарекува сунети, а често се нарекува и свадба (сунет-свадба). Зурлаџиската музика е присутна и за време на некои верски празници и кај муслиманското и кај христијанското население, за време на одржувањето на пеливански борби, како дел од ансамблите кои ја негуваат традиционалната музика и игра, и на фестивалски сцени каде што зурлаџиската музика ги напушта претходноспоменатите контексти, но станува достапна за поширокиот аудиториум. Александар Линин посочува обичај во Струмичко поле, кога за време на жетвата се канеле зурлаџиско-тапанарските состави, кои за време на починка свиреле, а наградата за нивниот труд се состоела во натура и пари (Линин 1986: 122). Денешните зурлаџии своето свирење го наплаќаат по однапред договорена сума, а во текот на свирењето заработуваат и дополнително од бакшишот кој го добиваат како награда од страна на задоволните луѓе и преку исполнувањето на музичките побарувања. Цените за кои свират струмичките зурлаџиски групи се релативно високи, што тие го оправдуваат со нивниот професионален однос и музичката подготвеност да одговорат на секое побарување во секоја прилика, без разлика кому му свират. Настапите на зурлаџискиот состав најчесто ги договара главниот зурлаџија (мајсторот), но и останатите членови од групата. Договарањето подразбира време и место на настап, за што однапред земаат одредена сума од договорената, со што си го осигуруваат својот ангажман.

\section{ЗАКЛУЧОК}

Произнесените информации ја отсликуваат состојбата на зурлаџиската традиција во Струмичкиот Регион. Опфатени се информации за видот на зурлите кои се употребувале и сѐ уште се употребуваат од страна на струмичките зурлаџии, информации кои се мошне значајни за едно органолошко истражување, и кои ќе претставуваат основа и за некои идни истражувања. Информациите за свирачите на зурла и тапан како главни двигатели и носители на инструменталната традиција, ни ја даваат состојбата со етничката и полова припадност која споредбено со минатото не е значајно променета. Опфатените зурлаџиски групи ја потврдуваат воспоставената практика на неделиво свирење на две зурли и еден тапан, практика која се применувала и во минатото, но ја забележавме и новата појава на свирење на 
три зурли и еден или два тапани, што во традицијата во Струмичкиот Регион, но и во останатите региони, е ретка појава. Опишаната техника на дување кај зурлаџиите, техника што си ја пренесуваат тие од колено на колено, исто така укажува на цврстата врска на зурлаџиите меѓу себе. Начинот на интерпретација на зурлаџиските мелодии и начинот на дување ни кажува дека оваа музика има свои специфичности, кои не се применуваат кај останатите народни инструменти. Посочените стилски карактеристики го отсликуваат задржаниот стар стил, бордунски и хетерофон, но и новата појава, дуплирање на бордунот и тригласната хетерофонија присутна кај групата составена од три зурли. Импровизациите и варијантноста кај зурлаџиската музика ја рефлектираат спонтаноста на фолклорната музика и ја истакнуваат индивидуалната подготвеност на мајсторот зурлаџија. Преку посочените контексти, ја согледавме практичната употреба на зурлаџиската музика во Струмичкиот Регион, музика што и денес има своја улога во животот на различните етнички заедници од овој регион. Како заокружување на нашето излагање, ќе ја потенцираме важната функција што ја има свирачот како најистакнат во процесот на создавање и на зачувување на оваа инструментална традиција. Свирачот со својот инструмент е тој што ја чува музиката наталожена и создавана во минатото, ја свири музиката што е актуелна во неговото време на живеење и создава музика во текот на неговото свирење, музика која понатаму ја пренесува на помладите генерации зурлаџии и тапанџии.

\section{ЛИТЕРАТУРА}

\section{Кирилични изданија}

Ангелов, Г. 2015. „Форми на изучување на вештините на свирење на музичкиот инструмент зурла“. Зборник на трудови од Музичко-научната манифестација „Струшка музичка есен“, Музика и образование, одржана на 12.-14.09.2014. Скопје: Сојуз на композитори на Македонија - СОКОМ, 7786.

Ангелов, Г. 2016. „Зурла - музички инструмент на еден етнос во Р. Македонија и Р. Бугарија“. Музика, бр. 22. Скопје: Сојуз на композитори на Македонија-СОКОМ, 67-79.

Качулев, И. 1962. „Народните инструменти и инструменталната музика

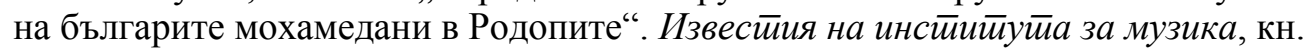
VIII. София: Издателство на БАН, 197-234.

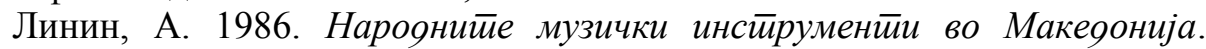
Скопје: Македонска книга.

Манолов, И. 1980. „Пирински край, Етнографски, фолклорни и езикови проучвания“. София: БАН, 561-623.

Симоновски, М. 1999. „Музичката терминологија во македонските

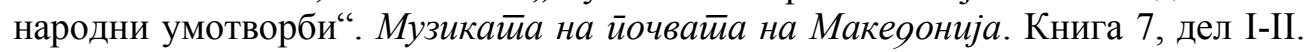
Скопје: МАНУ, 207-217. 


\section{Латинични изданија}

Angelov, G. 2016. „,The function of the zurla players in the pelivan wrestling, in some parts of the Republic of Macedonia“. Proceedings of the Fourth Symposium of the ICTM Study Group on Music and Dance in Southeastern Europe New scopes of research and action held on 24 September - 1 October, 2014, at Petnica Science Center, Republic of Serbia. Belgrade: Faculty of Music; University of Arts, 99-106.

Dević, D. 1977. Etnomuzikologija (Instrumenti - III deo). Skripta. Beograd: Fakultet umetnosti u Beogradu.

Gojković, A. 1983. „O muzici Roma“. Zvuk, br. 1. Sarajevo, 71-75.

Gojković, A. 1989. Narodni muzički instrumenti. Beograd: Vuk Karadžić.

Hoerburger, F. 1986. Volksmusik forschung: Aufsätze und Vorträge 19531984 über Volkstanz und instrumentale Volksmusilk. Laaber: Laaber-Verlag.

Širola, B. 1932. Sopile i zurle. Narodna starina, knjiga XII, sv. 30. Zagreb: Etnografski muzej.

\section{ИНФОРМАТОРИ}

Абди Сулејманов, зурлаџија од с. Банско, Струмички Регион, роден 1988 г. во Штип (А.С.)

Демир Мемедов, зурлаџија и тапанџија од Струмица, роден 1955 г. во Струмица (Д.М.).

Ихмет Усеинов-Ико, зурлаџија, роден 1981 г. во Велес (И.У.). J.).

Себатит Јусеинов, зурлаџија и тапанџија, роден 1965 г. во Струмица (С.

Садик Сулејманов, зурлаџија, роден 1969 г. во Штип (С.С.).

Gorančo Angelov

THE 21 CENTURY'S ZURLA TRADITION IN THE STRUMICA REGION

Summary

The paper researched the so called "zurla" and "drum" ensembles in the Strumica region which are alive and relevant even today, in the era of globalization, and they successfully remain relevant among the contemporary musical instruments that slowly replace the traditional ones. The research of these music instruments in the Strumica region allowed us to evaluate the current situation of these instruments nowadays (the zurla and the drum) and we also gathered valuable information from the people responsible of keeping this tradition alive in the $21^{\text {st }}$ century. 


\section{ПРИЛОЗИ \\ Фотографии}

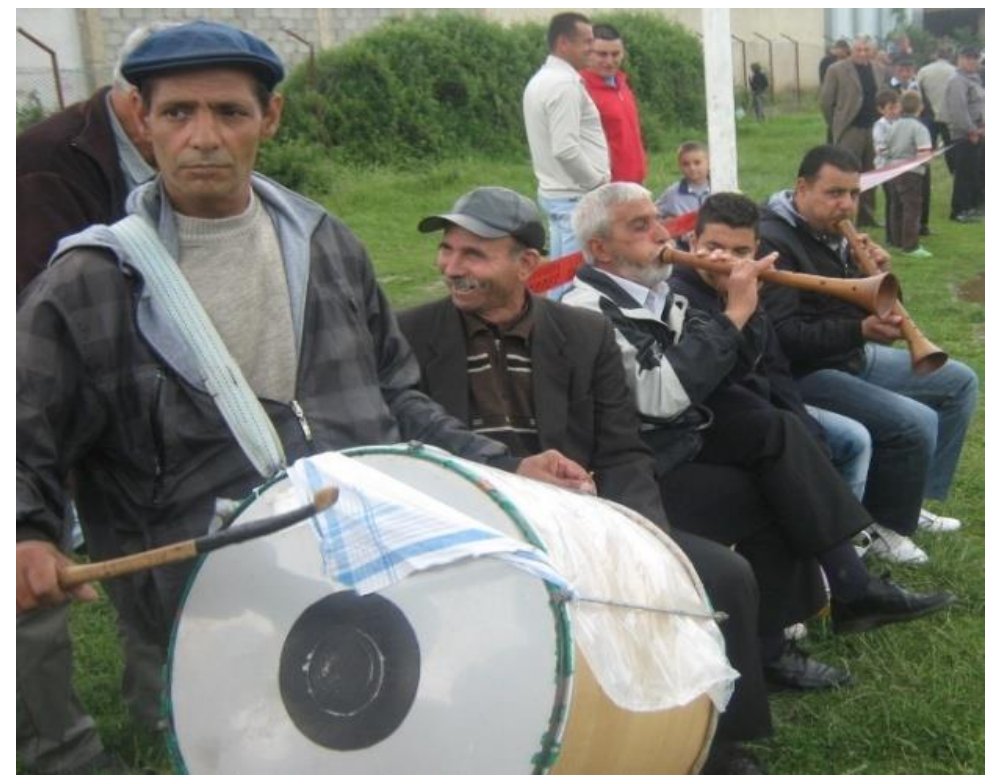

Фотографија 1: Демир Мемедов (зурла), Изет Абдиев (зурла) и Себатит Јусеинов (тапан).

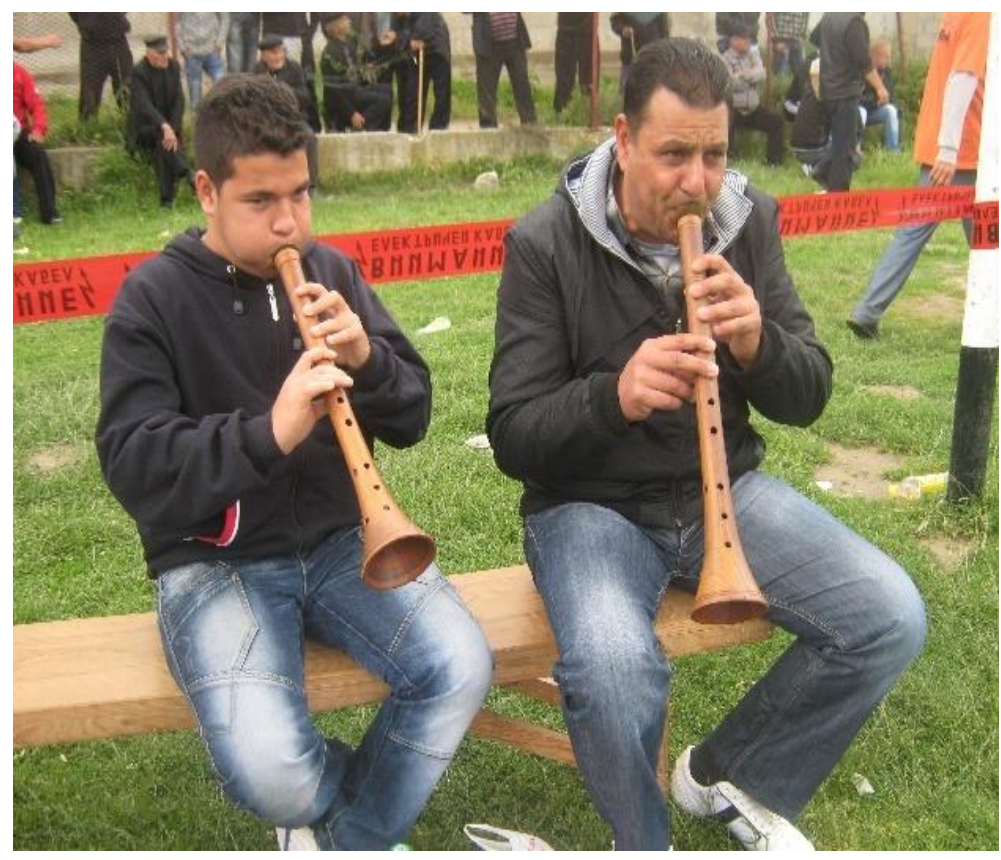

Фотографија 2: Себатит и Изет Абдиеви. 


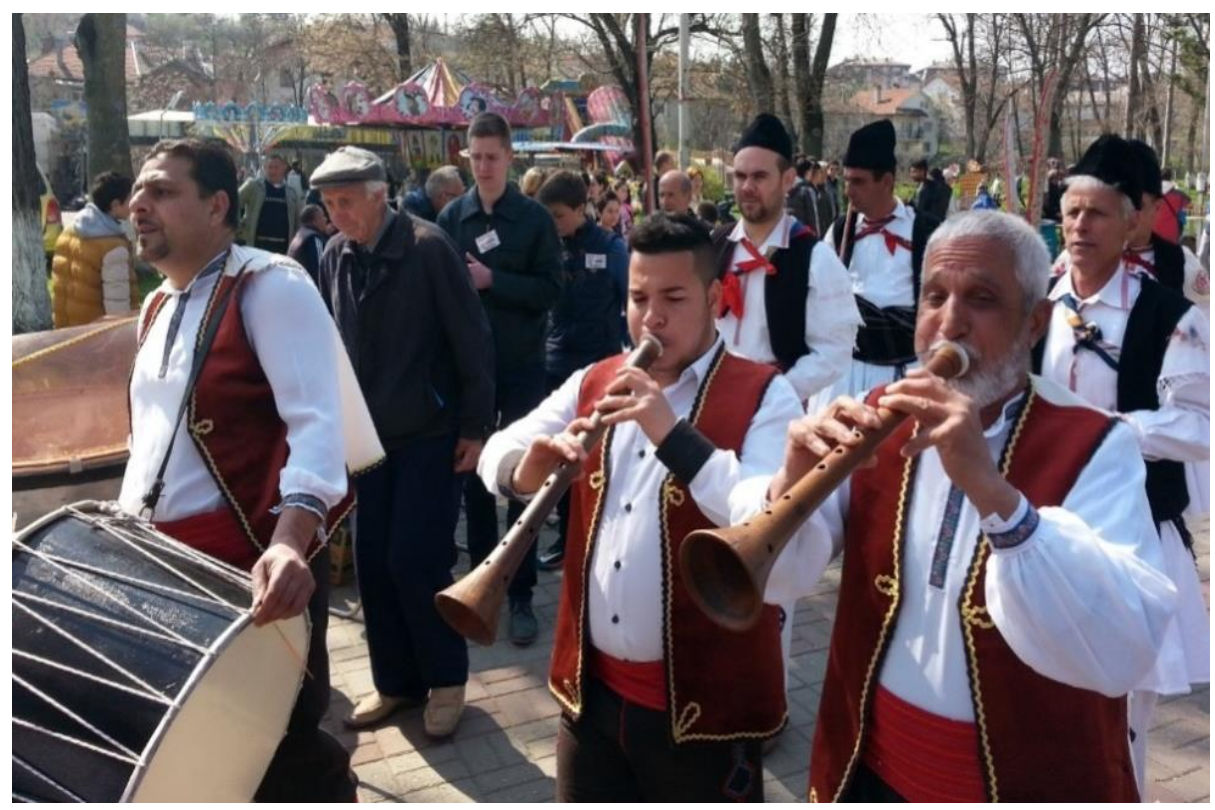

Фотографија 3: Изет Абдиев (тапан), Себатит Абдиев (зурла) и Демир Мемедов (зурла).

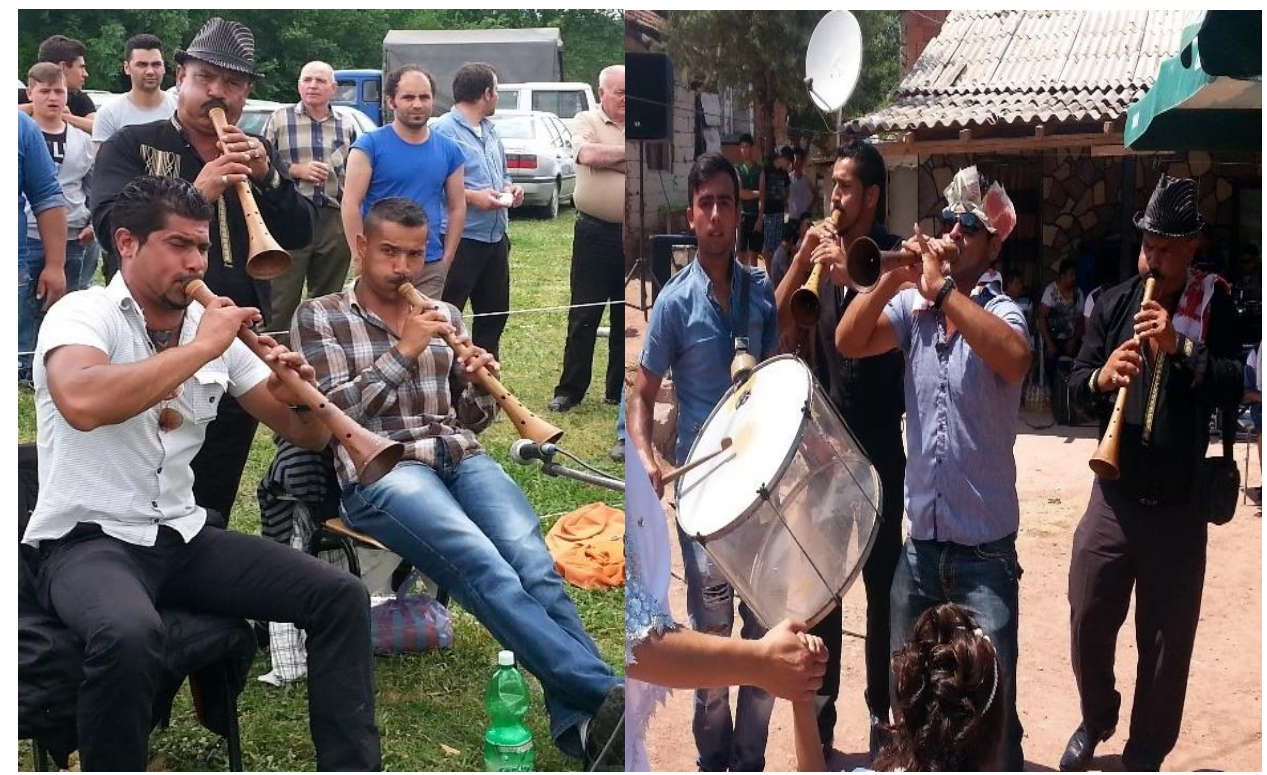

Фотографија 4: Садик, Абди и Амте Сулејманови (зурли) и Рустем Мустафов (тапан). 


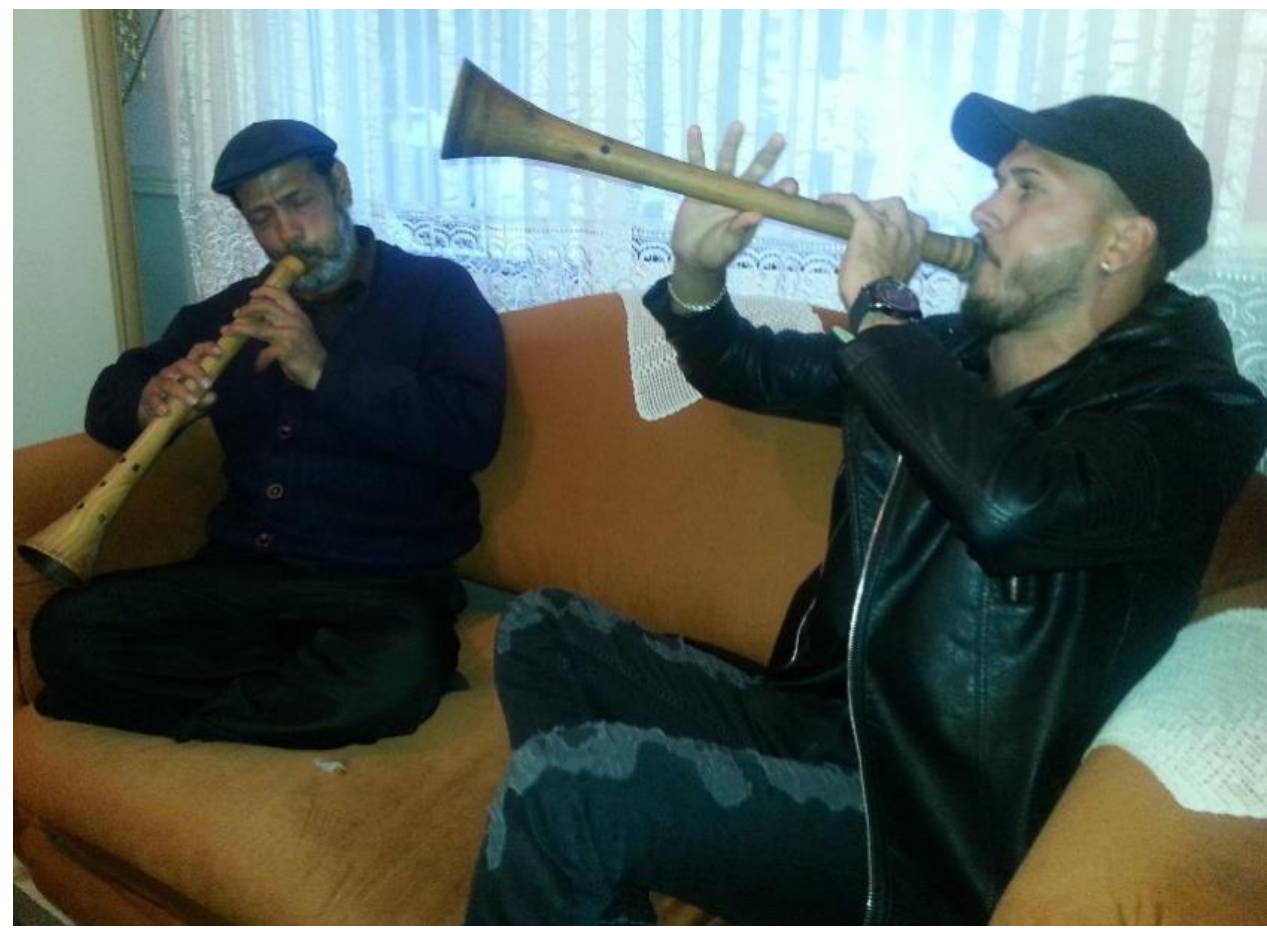

Фотографија 5: Себатит Јусеинов и Џејан Агушев. 
НАУЧНИ СТАТИИ 